\title{
PENGEMBANGAN MEDIA PEMBELAJARAN BERBASIS VIDEO PADA PEMBELAJARAN DARING DI MASA PANDEMI COVID-19
}

\author{
Novalia $^{1 *}$, Adelina Anum ${ }^{2}$ \\ ${ }^{(1)(2)}$ Universitas Sang Bumi Ruwa Jurai \\ ${ }^{(1)}$ novaliasholehah@mail.com, ${ }^{(2)}$ punya.adel@gmail.com
}

\begin{abstract}
Abstrak.
Pemerintah melalui kementerian pendidikan dan kebudayaan menerbitkan surat edaran nomor 3 tahun 2020 tentang pencegahan covid-19 pada satuan pendidikan sebagai antisipasi terhadap penyebaran virus corona di sekolah maupun perguruan tinggi. Menindaklanjuti surat edaran tersebut, perguruan tinggi meniadakan pembelajaran secara tatap muka. Pada pembelajaran daring dosen perlu melakukan modifikasi/pengembangan bahan ajar agar mahasiswa tidak mengalami kesulitan dalam memahami materi. Tujuan penelitian ini yaitu menghasilkan produk berupa media pembelajaran berbasis video pada mata kuliah statistik ekonomi. Penelitian ini dilaksanakan di Fakultas Ekonomi Universitas Sang Bumi Ruwa Jurai Bandar Lampung. Penelitian dilaksanakan dari bulan juli sampai dengan bulan oktober 2020. Penelitian ini merupakan penelitian pengembangan (research and development). Produk yang dikembangkan berupa media pembelajaran berbasis video pada mata kuliah statistika ekonomi. Model penelitian pengembangan yang digunakan adalah model Plomp. Video pembelajaran ini dinilai oleh ahli media, teman sejawat dan ahli materi serta mahasiswa. Aspek yang dinilai sesuai dengan keahliannya masing-masing. Setelah dialakukan analisis deskriptif diperoleh kesimpulan bahwa rata-rata pilihan jawaban angket penilaian video pembelajaran oleh validator ahli dan mahasiswa yaitu 3,443 atau jika diprosentasekan $86,085 \%$ yang artinya menurut tiga validator dan mahasiswa video pembelajaran mata kuliah statistik ekonomi 2 materi pengujian hipotesis yang dibuat sangat layak digunakan sebagai salah satu alternatif dalam pembelajaran daring yang dilakukan selama masa pandemi covid-19.
\end{abstract}

Kata kunci: Video Pembelajaran, Statistika, covid-19

\begin{abstract}
.
The government, through the education and culture ministry, issued circular number 3 of 2020 concerning the prevention of covid-19 in education units in anticipation of the spread of the corona virus in schools and colleges. Following up on this circular, the college eliminated face-to-face learning. In online learning, lecturers need to modify / develop teaching materials so that students do not experience difficulties in understanding the material. The purpose of this research is to produce a product in the form of video-based learning media in economic statistics courses. This research was conducted at the Faculty of Economics, Sang Bumi Ruwa Jurai University in Bandar Lampung. The research was conducted from July to October 2020. This research is a research and development study. The product developed is in the form of videobased learning media in economic statistics courses. The research and development model used is the Plomp model. These instructional videos were assessed by media experts, peers and material experts as well as students. The aspects that are assessed are in accordance with their respective expertise. After the descriptive analysis was carried out, it was concluded that the average choice of answers to the learning video assessment questionnaire by expert validators and students was 3.443 or if it was proxied $86.085 \%$, which means that according to the three validators and students, the learning videos for the economic statistics course 2 hypothesis testing material made was very feasible as an alternative to online learning during the Covid-19 pandemic.
\end{abstract}

Keywords: Learning Videos, Statistics, covid-19

\section{PENDAHULUAN}

Wabah virus corona terjadi sejak akhir tahun 2019 di Wuhan Propinsi Hubei China. Wabah ini meluas ke seluruh penjuru dunia, termasuk Indonesia. Pasien positif penderita covid-19 terus mengalami peningkatan. Pemerintah melalui kementerian pendidikan dan kebudayaan menerbitkan 
surat edaran nomor 3 tahun 2020 tentang pencegahan covid-19 pada satuan pendidikan sebagai antisipasi terhadap penyebaran virus corona di sekolah maupun perguruan tinggi. Menindaklanjuti surat edaran tersebut, perguruan tinggi meniadakan pembelajaran secara tatap muka. Pembelajaran di perguruan tinggi diadakan secara daring dengan menggunakan berbagai macam aplikasi, seperti Google Classroom, Zoom, group WhatsApp dan lain sebagainya.

Survei mengenai pembelajaran daring pada masa pandemi sudah dilakukan di Universitas Pendidikan Indonesia (UPI). Hasil dari survei menunjukan 40,3\% mahasiswa yang setuju dengan adanya pembelajaran daring, penilaian mahasiswa pada unjuk kerja dosen dalam pembelajaran daring ini sebanyak 51,9\% mahasiswa menilai cukup baik, pada proses pembelajaran daring sebanyak 38,9\% menurut mahasiswa para dosen kampus UPI membuat bahan ajar dan mengembangkannya sendiri dan sebanyak 36,1\% melakukan modifikasi bahan ajar untuk pembelajaran daring. Masalah-masalah yang dihadapi selama pembelajaran daring antara lain kesulitan jaringan, ketersediaan perangkat pembelajaran, tingkat pemahaman materi, suasana rumah dan lingkungan sekitar yang tidak mendukung (http://berita.upi.edu/25031/).

Pada pembelajaran daring dosen perlu melakukan modifikasi/pengembangan bahan ajar agar mahasiswa tidak mengalami kesulitan dalam memahami materi terutama mata kuliah eksak yang banyak proses perhitungannya. Pengembangan media pembelajaran interaktif berbasis animasi layak digunakan dan dapat membantu jalannya proses pembelajaran matematika pada materi statistika (Widjayanti dkk; 2018). Media pembelajaran adalah alat bantu untuk menyampaikan pesan dan mempermudah dalam mempelajari sesuatu. Menurut Mustholiq, dkk dalam Fauzan, M. Aziz dan Dwi (2017) "Media pembelajaran mempunyai peran yang sangat penting dalam proses belajar mengajar, karena dapat membuat suasana belajar menjadi lebih hidup dan bermakna". Peran Teknologi Informasi Komunikasi (TIK) di bidang pendidikan sangat dibutuhkan yaitu dengan penggunaan media pembelajaran yang memanfaatkan TIK. Penggunaan media pembelajaran yang memanfaatkan TIK dapat menjadikan pembelajaran matematika lebih mudah dan menarik. Menurut Neuman \& Hood dalam Widjayanti (2018) "penggunaan simulasi berbasis komputer, multimedia dan animasi pada pembelajaran menunjukkan aplikasi praktis statistik, membantu memahami statistik, dan mengatasi sikap negatif terhadap statistik. Berdasarkan beberapa penelitian yang telah ada, peneliti tertarik untuk mengembangkan media pembelajaran berbasis video pada mata kuliah statistik ekonomi. Media pembelajaran berbasis video di perguruan tinggi masih minim, rata-rata media pembelajaran berbasis video dikembangkan di tingkat sekolah. Penelitian ini penting untuk dilakukan agar hasilnya dapat segera digunakan dalam pembelajaran daring.

Tujuan penelitian ini yaitu menghasilkan produk berupa media pembelajaran berbasis video pada mata kuliah statistik ekonomi. Video pembelajaran yang akan dibuat menggunakan aplikasi adobe premier, pada aplikasi ini video pembelajaran akan dilengkapi dengan animasi-animasi yang dapat membuat video pembelajaran lebih menarik. Video pembelajaran yang menarik diharapkan mampu membantu mahasiswa dalam memahami materi statistik ekonomi. Tujuan dari penelitian ini yaitu menghasilkan produk berupa media pembelajaran berbasis video untuk mata kuliah statistik ekonomi II materi pengujian hipotesis.

\section{METODE PENELITIAN}

Penelitian ini dilaksanakan di Fakultas Ekonomi Universitas Sang Bumi Ruwa Jurai yang beralamat di Jalan Imam Bonjol No. 468 Langkapura Kota Bandar Lampung. Penelitian dilaksanakan dari bulan juli sampai dengan bulan oktober 2020. Penelitian ini merupakan penelitian pengembangan (research and development). Produk yang dikembangkan berupa media pembelajaran berbasis video pada mata kuliah statistika ekonomi. Model penelitian pengembangan yang digunakan adalah model Plomp.

Penelitian ini merupakan penelitian pengembangan (research and development) dengan menggunakan model plomp. Penerapan model Plomp menggunakan lima fase, yakni preliminary 
investigation (fase investigasi awal), design (fase desain), realization/construction (fase realisasi/kontruksi), test, evaluation and revision (tes, evaluasi dan revisi, dan implementation (implementasi). Diagram alur model Plomp dapat dilihat pada Gambar 1.

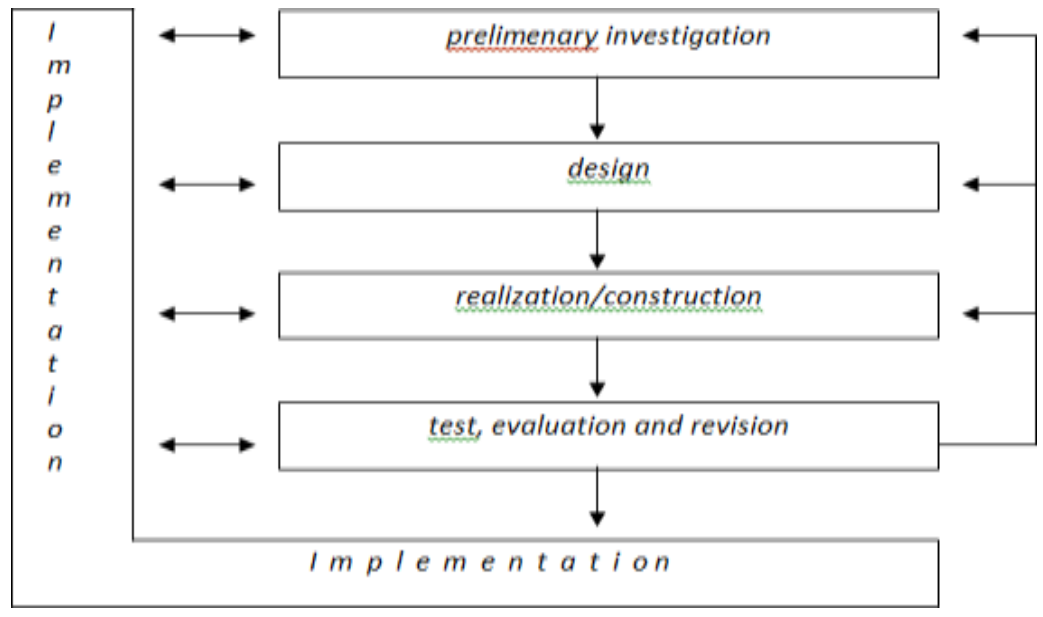

\section{Gambar.1 Diagram Alur Model Plomp (Sumber: Rochmad, 2012)}

Berdasarkan Gambar.1 terlihat alur dari model plomp, terdapat 5 fase. Berikut penjelasan mengenai kelima fase tersebut :

1. Fase investigasi

Pada fase pertama ini, peneliti menganalisis masalah atau menganalisis kebutuhan seperti mengumpulkan dan menganalisis informasi, definisi masalah, dan rencana lanjutan dari projek.

2. Fase Desain

Pada fase kedua ini, peneliti mendesain pemecahan masalah dengan hasil rencana kerja atau rencana tertulis yang akan direalisasikan pada fase realisasi. Peneliti membuat naskah video pembelajaran sesuai dengan rps dan sap.

3. Fase realisasi/konstruksi

Pada fase ketiga ini, peneliti melakukan pembuatan video pembelajaran. Pembuatan video pembelajar diawali dengan proses perekaman video, kemudian untuk lebih menarik video yang dibuat ditambahkan gambar-gambar yang dibutuhkan agar video lebih menarik.

4. Fase tes, evaluasi, dan revisi

Pada fase ini, video yang sudah dibuat akan diujikan ke mahasiswa. Video akan mendapatkan penilaian dari validator dan mahasiswa. Setelah diievaluasi video akan direvisi sesuai dengan evaluasi yang diberikan validator dan mahasiswa.

5. Fase implementasi.

Pada fase ini, video pembelajaran yang sudah direvisi diimplementasikan dalam pembelajaran daring.

Variabel yang diamati dalam penelitian ini yaitu kelayakkan/kualitas media pembelajaran berbasis video. Kelayakan/kualitas media pembelajaran berbasis video diukur dengan menggunakan angket. Angket disebarkan ke 3 orang ahli dan mahasiswa yang mengambil mata kuliah statistik ekonomi.

Populasi dalam penelitian ini adalah seluruh mahasiswa Fakultas Ekonomi yang mengambil mata kuliah Statistik Ekonomi. Sampel yang digunakan sama dengan populasi penelitian ini yaitu seluruh mahasiswa Fakultas Ekonomi yang mengambil mata kuliah Statistik Ekonomi. Instrumen yang digunakan yaitu angket, angket mengenai kelayakan/kualitas media pembelajaran berbasis video yang digunakan.

Analisis data yang digunakan dalam penelitian ini, yaitu analisis data kualitatif. Data kualitatif diperoleh dari angket yang disebarkan ke validator dan mahasiswa. Angket yang disebarkan 
menggunakan skala likert dengan menggunakan pilihan ganjil. Skala yang digunakan dalam penelitian pengembangan ini adalah lima skala yaitu 1, 2, 3, 4 dan 5. Skala 1 merupakan dalam kategori terendah dan skala 5 dalam kategori tertinggi. Masing-masing skala mempunyai indikator yang berbeda-beda sesuai dengan tingkatannya. Menurut Riduwan (2012: 89) persentase untuk tiaptiap sub variabel dihitung menggunakan rumus:

$$
R S=\frac{n}{N} \times 100 \%
$$

Keterangan: RS : persentase sub variabel

$\mathrm{n}$ : jumlah nilai setiap sub

$\mathrm{N}$ : jumlah skor maksimum

Berdasarkan skor prosentase yang diperoleh ditransformasikan ke dalam kalimat yang bersifat kualitatif. Rentang prosentase dan kriteria kualitatif menurut Riduan (2012) dapat dilihat pada Tabel.1.

Tabel.1. Range Prosentase dan Kriteria Media Pemebelajaran

\begin{tabular}{ccc}
\hline No & Range prosentase & Kriteria \\
\hline 1. & $81 \%-100 \%$ & Sangat baik/layak \\
2. & $61 \%-80 \%$ & Baik/layak \\
3. & $41 \%-60 \%$ & sedang \\
4. & $21 \%-40 \%$ & buruk \\
\hline
\end{tabular}

\section{HASIL DAN PEMBAHASAN}

Penelitian ini merupakan penelitian pengembangan (research and development) dengan menggunakan model plomp. Penerapan model Plomp menggunakan lima fase, yakni preliminary investigation (fase investigasi awal), design (fase desain), realization/construction (fase realisasi/kontruksi), test, evaluation and revision (tes, evaluasi dan revisi), dan implementation (implementasi).

Pada fase investigasi, hal yang dilakukan yaitu merupakan langkah awal penelitian. Peneliti menginvestigasi hal-hal yang dibutuhkan mahasiswa dalam pembelajaran daring. Mahasiswa membutuhkan lebih dari sekedar materi yang disajikan dalam bentuk power point. Oleh karena itu, peneliti berusaha membuat video pembelajaran. Video pembelajaran yang dihasilkan adalah video pembelajaran statistika dengan materi pengujian hipotesis. Video pembelajaran ini merupakan perpaduan video pembelajaran dosen ketika menerangkan dikombinasikan dengan materi yang disajikan dalam power point. Materi pengujian hipotesis merupakan materi awal dalam pembelajaran statistik ekonomi II. Mahasiswa harus memahami materi pengujian hipotesis terlebih dahulu, agar dapat memahami materi-materi statistika ekonomi II berikutnya.

Fase kedua yaitu fase design, peneliti mendesign video pembelajaran. Peneliti membuat RPS dan materi dalam bentuk power point. Peneliti menyusun skenario video pembelajaran. Fase ketiga, peneliti melakukan pembuatan video pembelajaran. Pembuatan video pembelajaran diawali dengan proses perekaman video, kemudian untuk lebih menarik video yang dibuat ditambahkan gambar-gambar dan musik yang dibutuhkan agar video lebih menarik.

Fase keempat yaitu fase tes, evaluasi dan revisi. Video pembelajaran yang sudah selesai dinilai oleh tiga validator ahli dan mahasiswa. Validator ahli terdiri dari validator media pembelajaran, validator materi (ahli statistika) dan validator teman sejawat. Ketiga validator 
dikirimkan link video dan link angket penilaian yang harus mereka isi. Analisis deskriptif dilakukan terhadap hasil angket ketiga validator. Validator media menilai 4 aspek yaitu perangkat lunak, tampilan gambar, suara dan komunikasi visual. Grafik hasil penilaian validator media dapat dilihat pada Gambar 2.

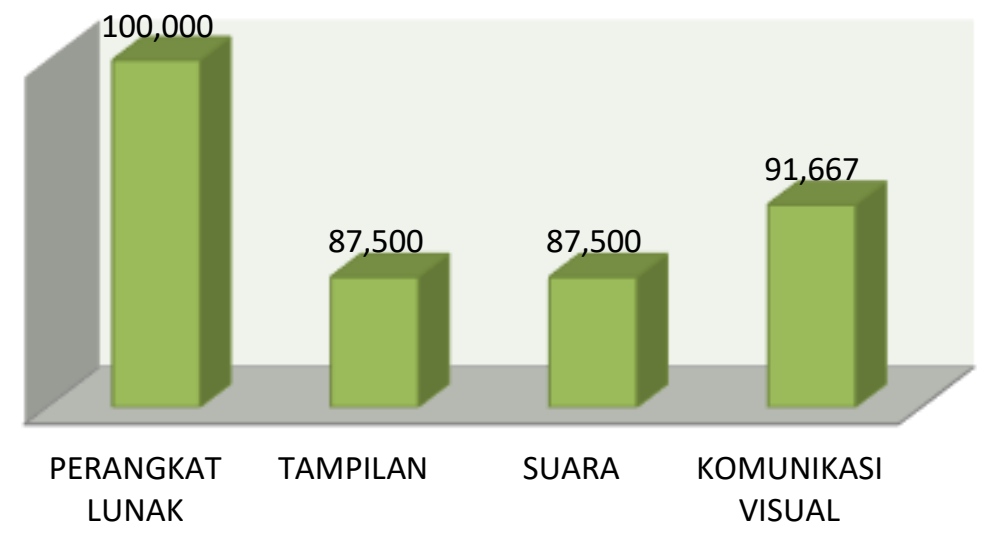

Gambar.2 Diagram Batang Penilaian Validator Ahli Media

Garmbar. 2 memperlihatkan bahwa hasil penilaian tertinggi yaitu perangkat lunak $100 \%$ (sangat layak) dan penilaian terendah yaitu tampilan dan suara 87,500\% (sangat layak). Rata-rata penilaian video pembelajaran oleh ahli media yaitu $91,667 \%$ artinya video pembelajaran ini sangat layak untuk digunakan. Video ini merupakan salah satu alternatif media pembelajaran untuk pembelajaran daring. Validator materi dan teman sejawat menilai 4 aspek yaitu aspek materi, bahasa, isi dan manfaat. Hasil penilaian vadidator materi dan teman sejawat dapat dilihat pada Gambar.3.

Garmbar.3 memperlihatkan bahwa hasil penilaian tertinggi yaitu aspek materi yaitu 83,3\% (sangat layak/sangat baik) dan penilaian terendah yaitu manfaat $80,000 \%$ (baik/layak). Rata-rata penilaian video pembelajaran oleh ahli materi yaitu $81,870 \%$ artinya video pembelajaran ini sangat layak untuk digunakan.

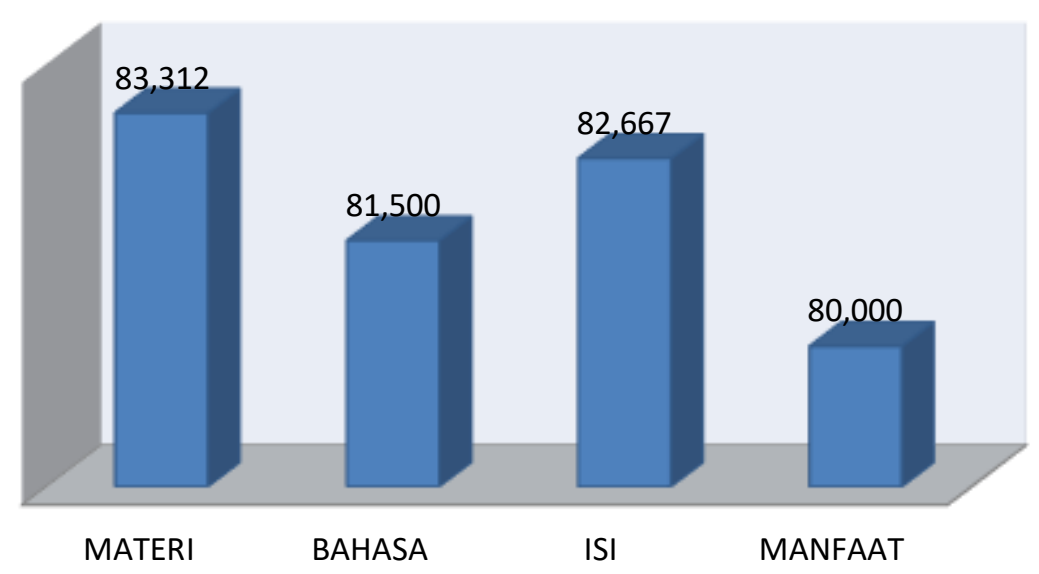

\section{Gambar 3. Diagram Batang Penilaian Validator Ahli Materi dan Teman Sejawat}

Penilaian video pembelajaran selanjutnya yaitu penilaian dari mahasiswa. Mahasiswa yang memberikan penilaian terhadap video pembelajaran ini yaitu mahasiswa yang mengambil mata kuliah statistik ekonomi II sebanyak 50 mahasiswa. Analisis deskriptif dari penilaian mahasiswa dapat dilihat pada Tabel 2. 
Seminar Nasional Penelitian dan Pengabdian kepada Masyarakat Universitas Sang Bumi Ruwa Jurai Tahun 2020

Tabel.2 Analisis Deskriptif Penilaian Mahasiswa

\begin{tabular}{lccccc}
\hline \multicolumn{1}{c}{ ASPEK } & MATERI & BAHASA & ISI & MANFAAT & TOTAL \\
\hline RATA-RATA & 3,428 & 3,420 & 3,440 & 3,400 & 3,428 \\
NILAI MINIMUM & 1,000 & 1,000 & 1,000 & 1,000 & 1,000 \\
NILAI MAKSIMUM & 4,000 & 4,000 & 4,000 & 4,000 & 4,000 \\
\hline
\end{tabular}

Tabel.3 memperlihatkan rata-rata total atau keseluruhan 3,428, nilai minimum 1 dan nilai maksimum 4. Berdasarkan keempat aspek penilaian yaitu materi, bahasa, isi dan manfaat, dari keempat aspek tersebut nilai rata-rata tertinggi yaitu aspek isi 3,440 dan nilai rata-rata terendah yaitu bahasa 3,420. Nilai minimum dan nilai maksimum untuk seluruh aspek materi, bahasa, isi, dan manfaat sama yaitu 1 dan 4 . Nilai terendah yang diberikan mahasiswa 1 dan nilai tertinggi yang diberikan mahasiswa 4. Diagram batang penilaian mahasiswa terhadap video pembelajaran dapat dilihat pada Gambar 4.

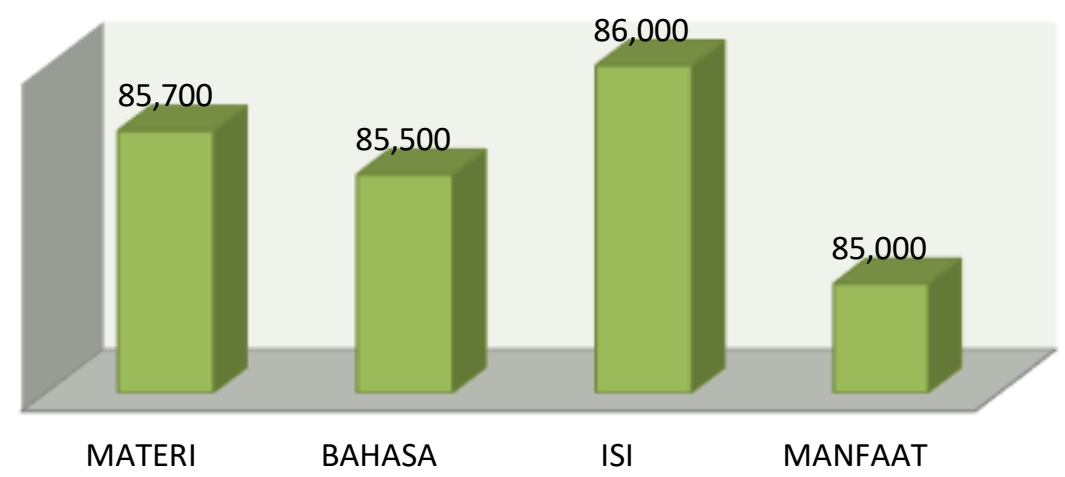

Gambar.4 Diagram Batang Penilaian Validator Mahasiswa

Gambar.4 memperlihatkan bahwa mahasiswa menilai video pembelajaran dari empat aspek yaitu aspek materi, bahasa, isi dan manfaat. Nilai tertinggi yaitu aspek isi sebesar $86 \%$ (sangat layak/sangat baik) dan nilai aspek terendah yaitu aspek manfaat yaitu 85\% (sangat layak/sangat baik). Rata-rata penilaian video pembelajaran oleh mahasiswa yaitu $85,700 \%$ artinya video pembelajaran ini sangat layak untuk digunakan.

Tiga orang validator ahli dan 50 mahasiswa memberikan penilai terhadap video pembelajaran melalui angket. Angket tersebut berisi 10 pertanyaan dengan pilihan jawaban 1 (tidak baik/tidak layak), 2 (cukup baik/cukup layak), 3(baik/layak) dan 4 (sangat baik/sangat layak). Rangkuman pilihan jawaban validator dan mahasiswa dapat dilihat pada Gambar 5.

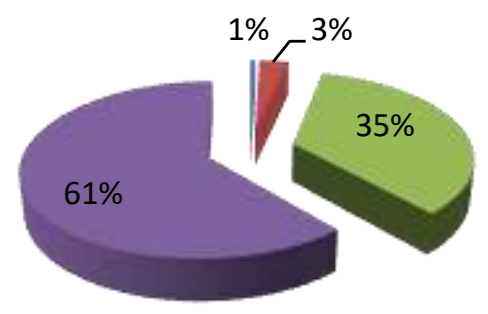

1 (TIDAK BAIK/TIDAK
LAYAK)
2 (CUKUP BAIK/CUKUP
LAYAK)
3 (BAIK/LAYAK)

\section{Gambar.5 Rangkuman Pilihan Jawaban Validator dan Mahasiswa}

Gambar.5 memperlihatkan bahwa 3 validator dan mahasiswa paling banyak memilih jawaban nomor 4 (sangat layak/sangat baik) yaitu sebanyak 61\%, kemudian nomor 3 (baik/layak), nomor 2 (cukup layak/cukup baik) dan pilihan jawaban yang paling sedikit memilih jawaban nomor 1 (tidak layak/tidak baik). Rata-rata pilihan jawaban angket penilaian video pembelajaran oleh validator ahli 
dan mahasiswa yaitu 3,443 atau jika diprosentasekan 86,085\% yang artinya menurut tiga validator dan mahasiswa video pembelajaran mata kuliah statistik ekonomi 2 materi pengujian hipotesis yang dibuat sangat layak digunakan sebagai salah satu alternatif dalam pembelajaran daring yang dilakukan selama masa pandemi covid-19.

Video pembelajaran mata kuliah statistik ekonomi II materi pengujian hipotesis yang diedit menggunakan adobe premier menghasilkan video yang menarik gabungan antara penjelasan dosen dan power point materi. Video dibagikan dalam bentuk link sehingga mahasiswa dapat mengaksesnya dengan mudah. Berdasarkan pendapat ahli media video sangat layak digunakan dari 4 aspek yaitu perangkat lunak, kualitas tampilan, aspek suara, dan aspek komunikasi visual. Ahli media menyarankan untuk menambahkan animasi yang lebih banyak lagi agar video lebih menarik dan mahasiswa lebih memahami materi yang disampaikan. Hal ini sesuai dengan pendapat peneliti sebelumnya yang mengungkapkan "media pembelajaran berbasis animasi dapat mengkonkretkan materi matematika yang abstrak sehingga memudah siswa memahami materi" (Altipamark: 2014).

Hasil analisis deskriptif jawaban angket ahli materi dan teman sejawat yaitu video pembelajaran mata kuliah statistik ekonomi II materi pengujian hipotesis sangat layak digunakan. Penilaian dilihat dari empat aspek yaitu aspek materi, kebahasaan, kelayakan isi dan aspek manfaat. Menurut ahli materi dan teman sejawat materi yang disampaikan dalam video sudah sesuai dengan teori, sesuai dengan RPS, runut dan lengkap sehingga video layak digunakan. Penilaian dari aspek materi memperoleh nilai yang paling tinggi dibandingkan empat aspek lainnya. Penilaian yang terendah yaitu dari aspek manfaat, video pembelajaran kurang mempermudah proses pembelajaran. Pembuatan video pembelajaran memang bukan suatu hal yang mudah bagi dosen, hal ini membutuhkan waktu, pikiran dan keahlian dalam bidang multimedia. Selain penilaian ahli media, ahli materi dan teman sejawat, penilaian mahasiswa juga merupakan hal yang penting.

Mahasiswa memberikan penilaian melalui angket yang disebarkan, penilaian dilihat dari 4 aspek yaitu aspek materi, kebahasaan, kelayakan isi dan aspek manfaat. Penilaian mahasiswa terhadap video pembelajaran memiliki hasil yang sama dengan penilaian ahli materi dan teman sejawat yaitu aspek materi memperoleh nilai tertinggi dan aspek manfaat memiliki nilai terendah. Ada beberapa mahasiswa yang berpendapat proses pembelajaran tatap muka lebih baik daripada pembelajaran daring. Pembelajaran daring membuat mahasiswa kesulitan dalam memahami materi, hal ini sesuai dengan survey yang dilakukan oleh tim peneliti UPI (http://berita.upi.edu/25031/). Ratarata penilaian video pembelajaran mata kuliah statistik ekonomi II materi pengujian hipotesis oleh mahasiswa yaitu $85,700 \%$ artinya video pembelajaran ini sangat layak untuk digunakan. Penilaian terhadap video pembelajaran mata kuliah statistik ekonomi II materi pengujian hipotesis dari ahli media, ahli materi, teman sejawat dan mahasiswa menghasilkan kesimpulan yang sama yaitu video pembelajaran yang dihasilkan layak untuk digunakan sebagai salah satu alternatif dalam pembelajaran daring di masa pandemi covid-19.

\section{KESIMPULAN}

Media pembelajaran berbasis video pada mata kuliah statistik ekonomi II materi pengujian hipotesis berhasil dikembangkan dengan model penelitian pengembangan Plomp. Video pembelajaran ini merupakan gabungan dari penjelasan dosen dan slide materi, dilengkapi dengan animasi serta musik pembuka. Video pembelajaran ini dinilai oleh ahli media, teman sejawat dan ahli materi serta mahasiswa. Aspek yang dinilai sesuai dengan keahliannya masing-masing. Setelah dialakukan analisis deskriptif diperoleh kesimpulan bahwa rata-rata pilihan jawaban angket penilaian video pembelajaran oleh validator ahli dan mahasiswa yaitu 3,443 atau jika diprosentasekan $86,085 \%$ yang artinya menurut tiga validator dan mahasiswa video pembelajaran mata kuliah statistik ekonomi 2 materi pengujian hipotesis yang dibuat sangat layak digunakan 
Seminar Nasional Penelitian dan Pengabdian kepada Masyarakat

Universitas Sang Bumi Ruwa Jurai Tahun 2020

sebagai salah satu alternatif dalam pembelajaran daring yang dilakukan selama masa pandemi covid19.

\section{UCAPAN TERIMAKASIH}

Peneliti mengucapkan terima kasih kepada Dosen, staf dan mahasiswa Universitas Sang Bumi Ruwa Jurai yang telah membantu jalannya penelitian ini .

\section{DAFTAR PUSTAKA}

Adam, steffi dan Muhammad T. (2015). "Pemanfaatan Media Pembelajaran Berbasis Teknologi Informasi Bagi Siswa Kelas X Sma Ananda Batam.” CBIS Journal 3 No 2(ISSN 23378794):78-90.

Altiparmak, K. (2014). Impact of computer animations in cognitive learning: Differentiation. International Journal of Mathematical Education in Science and Technology, 45(8), 11461166. Diambil dari https://eric.ed.gov/?q=Altiparmak\&id=EJ1044537

Fauzan, Muhammad Aziz, and Dwi Rahdiyanta. (2017). "Pengembangan Media Pembelajaran Berbasis Video Pada Teori Pemesinan Frais.” Jurnal Dinamika Vokasional Teknik Mesin 2(2):82.

Kreano, Jurnal. (2017). "Desain Model Pengembangan Perangkat Pembelajaran Matematika." Kreano: Jurnal Matematika Kreatif-Inovatif 3(1):59-72.

Raharjo, Raharjo. (2014). "Pengembangan Video Tutorial Pada Mata Kuliah Pengantar Statistika Pendidikan Untuk Pembelajaran E-Learning." Jurnal Ilmiah Mimbar Demokrasi 14(1):59-78.

Widjayanti, Wigita Rezky, Titin Masfingatin, and Reza Kusuma Setyansah. (2018). "Media Pembelajaran Interaktif Berbasis Animasi Pada Materi Statistika Untuk Siswa Kelas 7 Smp." Jurnal Pendidikan Matematika 13(1):101-12.

Widya, Tenny. (2012). "Pengembangan Media Video Pembelajaran Pertempuran Di Surabaya Untuk Siswa Kelas IX Smp Negeri 1 Kalitidu- Bojonegoro.” Jurnal Pendidikan Sejarah $1(2): 1-8$. 